\title{
Transatlantica
}

Revue d'études américaines. American Studies Journal

\section{Poets and Puppets: Interarts Collaboration in Alfred Kreymborg's Lima Beans}

\section{Yasna Bozhkova}

\section{(2) OpenEdition \\ Journals}

Electronic version

URL: https://journals.openedition.org/transatlantica/14707

DOI: 10.4000/transatlantica. 14707

ISSN: 1765-2766

\section{Publisher}

Association française d'Etudes Américaines (AFEA)

Electronic reference

Yasna Bozhkova, "Poets and Puppets: Interarts Collaboration in Alfred Kreymborg's Lima Beans",

Transatlantica [Online], 2 | 2019, Online since 15 September 2020, connection on 03 February 2023.

URL: http://journals.openedition.org/transatlantica/14707 ; DOI: https://doi.org/10.4000/

transatlantica. 14707

This text was automatically generated on 3 February 2023.

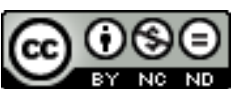

Creative Commons - Attribution-NonCommercial-NoDerivatives 4.0 International - CC BY-NC-ND 4.0 https://creativecommons.org/licenses/by-nc-nd/4.0/ 


\title{
Poets and Puppets: Interarts Collaboration in Alfred Kreymborg's Lima Beans
}

\author{
Yasna Bozhkova
}

Here was a clear case of what fine synthesis an experimental stage could give when a poet wrote, when poets spoke and when a poet-painter painted. ${ }^{1}$

1 In December 1916 in New York, poet Alfred Kreymborg, today more well-known as the editor of the modernist little magazine Others, cast poets Mina Loy and William Carlos Williams as husband and wife in his one-act play Lima Beans. Lima Beans was Kreymborg's first foray into the realm of playwriting, and was later published as part of his collection Plays for Poem-Mimes in 1918, reprinted as Puppet Plays in 1923. William Zorach, a poet and artist whose work also later appeared in Others, played the third part, a vegetable huckster. He also designed the set, which included a curtain festooned with vegetables-listed in the stage directions as the fourth cast member-, and a Futurist checkerboard backdrop radically at odds with the play's apparently realist and simple story, representing the banal quotidian of a married couple. The play was officially produced by the Provincetown Players, although even the members of this avant-garde group, one of the most innovative theater groups on American soil at the time, were nonplussed by the experimental, non-representational performance. The play indeed combined a proto-absurdist take on everyday life and marriage with abstract sets and innovative acting techniques breaking with the illusion of mimesis typical of the theater of the time. Influenced by Gordon Craig's work with puppets, as he explained in the stage directions, Kreymborg wanted to stage the three poets as "marionnettes" (1918 43), whose dialogues were to be understood as rhythmical free verse and whose mechanical gestures he orchestrated with a baton, thus creating a radical estrangement effect from the mundane, realistic story of husband and wife that the play represents. 
2 This article focuses on the idea of a collaboration across the arts between the two poets and Zorach, a poet-artist, as amateur actors with Kreymborg, who was also a poet himself, as well as the editor of the magazine that brought their work to prominence. As Suzanne Churchill has argued, Others was highly influential in creating a space for experimentation in American poetry, ${ }^{2}$ and little magazines like Others "served as stages for experimental literary productions [...] as experimental performance spaces, more similar to theaters than to books" (2017 n. p.). In the light of this statement, it is surprising that the possible intertextual and intermedial connections between the work that appeared in Others and this performance that involved the little magazine's leading figures have remained unexplored. Furthermore, while other studies focusing on the related and partially overlapping Arensberg circle have emphasized the strategic importance of community and improvisational collaborative practices, as well as the productive exchanges between the arts, ${ }^{3}$ this case of modernist theater collaboration between poets is often omitted or briefly mentioned in passing as a simple amusing anecdote. While theater, unlike poetry or painting, is by definition a collaborative art, I argue that this case of modernist theater collaboration is unique in the far-reaching relationships between the page and the stage, and between the different arts, that it created. Lima Beans gains in importance when examined alongside the poems of Loy and Williams that appeared in Others in this period. I begin by examining the production's innovative, experimental aesthetics, which goes against the grain of the realist theater favored by the Provincetown Players. I show that the play strategically engages with and parodies this tradition through a certain number of abstract, proto-absurdist or de-naturalizing elements, thus subtly navigating between various conflicting strands of European and American avant-garde. I then focus on Kreymborg's attempt to create a unique interarts synthesis, bridging the gap between arts as varied as drama, poetry, puppet theater, music, dance, and pantomime in his "puppet plays." This blurring of generic boundaries, it is worth mentioning, was reinforced in the case of the production of Lima Beans by the strategic casting of key players of the nascent American poetic modernism in the main parts, and by Kreymborg's own overlapping roles as the editor of Others on the one hand and as the "Wire-Puller" (Loy, 1997 55) of the puppet-characters of Lima Beans on the other. Finally, focusing on the intertextual dialogues between the play and the poems of Loy and Williams published in Others in this period, I explore the ironic blurring of the play's proto-absurdist characters with the poets' textual personae: the Futurist sets designed by Zorach specifically alluded to Loy's experience with the Italian Futurists in Florence, while the quotidian dialogues between husband and wife read as a reference to the feminist deconstruction of "marriage boxes"4 in her early poems, even as they engaged with William Carlos Williams's modernist poetics centered on the everyday.

\section{The Other Provincetown Players: Against the Grain of Realist Theater}

3 As Brenda Murphy recounts in her book The Provincetown Players and the Culture of Modernity, Kreymborg was introduced to the Provincetown Players by William Zorach: "Frustrated with the bias towards realism that seemed to be emerging in the Players" (Murphy 106), Zorach urged Kreymborg to submit his work to their play-reading committee. Although the play was immediately rejected by the committee, the Players 
eventually agreed to produce it, though not without a certain reticence: in fact, they did so only because John Reed threatened to resign from the group. There was a rather strained relation between the Players and the Others group, since it was obvious that the Players observed the rehearsals with "skeptical bemusement" (Murphy 107). Although the performance was a qualified success rather than a flop as the Players had expected, the tensions continued, and the Players' attempts to thwart their experimentation with nonrepresentational elements eventually prompted Kreymborg and the Zorachs to create their own group, called the "Other players." While the Provincetown Players were one of the first groups to renovate American theater in the twentieth century, launching the careers of such leading American playwrights as Eugene O'Neill, their work remained firmly ingrained in a tradition of realist drama. As Burke explains, “Most Players preferred Eugene O'Neill's Before Breakfast, a one-acter on the same bill as Lima Beans which consisted of a shrewish wife's monologue, followed by her offstage husband's slitting his throat-a depressive foil to Kreymborg's lighthearted romp" (Burke 222n).

4 One need take but a single look at the only surviving photograph [Ill. 1] that documents the December 1916 performance of Lima Beans, which captures the abstract, stark black-and-white sets, and the actors' stilted, mechanical gestures, in order to understand why spectators accustomed to the conventions of realist theater would find the performance baffling.

III. 1. Loy and Williams in the Provincetown Players production of "Lima Beans" (1916).

Permission courtesy of Roger Conover, Mina Loy's editor and literary executor.

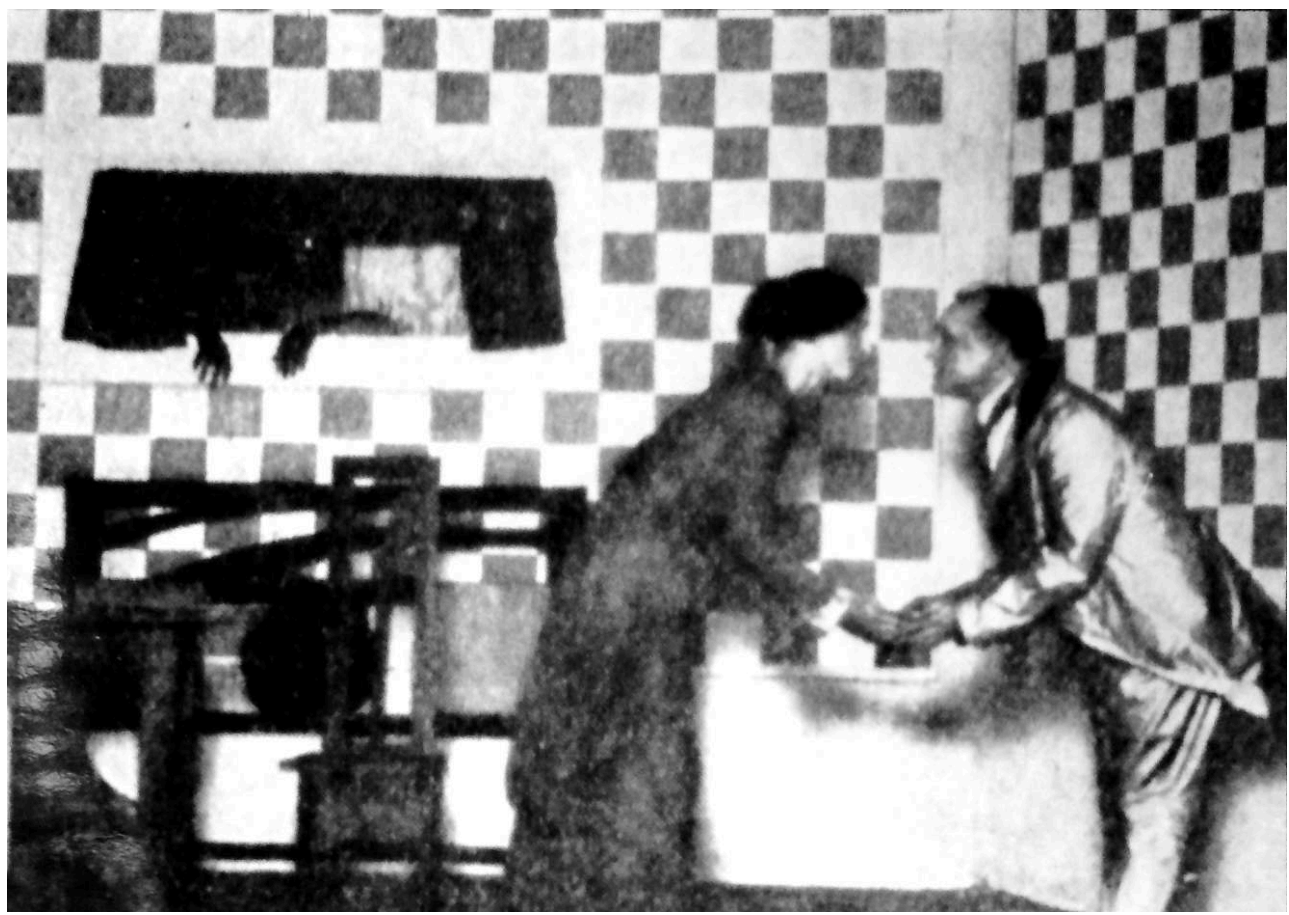

If on one level the plot of the play may seem like a half-hearted attempt to abide by the rules of realist family dramas-a domestic setting, a family conflict, a bland, unembellished, everyday dialogue-, in order to be accepted by the Players, on another level it reads as a parody of such conventions. The characters, lacking names, listed simply as "She," "The Wife," and "He" and "The Husband" respectively, and sometimes 
referred to as Mr. and Mrs. Lima by Kreymborg in his memoirs, are obviously flat characters, embodiments of stereotypical gender roles, and deprived of any kind of psychological depth, complexity, or motivation. The plot takes the somewhat fatuous rituals of domesticity and married life to the point of absurdity: the loving "Wife" decides to give her husband a break from their regular meal of lima beans, which they have been having every night, opting for string beans instead; she then greets her husband who has just come back from work; upon seeing the string beans her husband throws a fit of violent anger for no apparent reason, throwing them out of the window; she hastily buys the habitual lima beans from the huckster and a scene of rather mawkish reconciliation between the two concludes the play. At regular intervals, the couple perform their ritual of embracing and kissing each other "daintily six times" (Kreymborg, 1918 47, 58). A multitude of elements combine to break with the illusion of mimesis that realist theater relies on and to create an effect of estrangement rather than identification with the story of this domestic drama. The omnipresent comedy of repetition, the nonsensical dialogues, or the fact that the vegetable-festooned curtain is listed as a member of the cast are all essentially proto-absurdist techniques, whose lineage may be traced back to Alfred Jarry's Ubu Roi (1896), with its puppet characters and cardboard sets, and which anticipate the techniques of much later absurdist plays like Eugène Ionesco's La cantatrice chauve (The Bald Soprano 1950). While the geometric black-and-white checkerboard sets could be seen as a realistic element, vaguely creating the illusion of a domestic space like a kitchen, on another level they clearly engage with the non-representational aesthetics of the most innovative European avant-garde currents-Futurism and Cubism. In fact, they strikingly resemble the sets of Anton Giulio Bragaglia's Thaïs (1917), the only surviving Futurist film. Designed by the Italian painter and scenographer Enrico Prampolini, the scenery of Thaïs created a similar stark contrast between black and white geometrical elements, providing an abstract backdrop to a less Futurist diegesis. In manifestos like "The Variety Theater" (1913) and "The Futurist Synthetic Theater" (1915), Marinetti and his fellow Futurists had violently attacked the principles of realism and verisimilitude that characterized traditional theater. In his 1915 manifesto "Futurist Set Design," Prampolini specifically called for the use of sets breaking the illusion of mimesis: "The stage is not a photographic enlargement of a rectangle of reality, nor even a relative synthesis of it; it is the replacement of reality with a theoretical and material system of subjective stage design, as distinct from the ostensibly objective scenography of today. [...] To conceive of the stage in itself, as a pictorial fact, is wrong" (Prampolini 212-213). Although Loy's own Futurist plays like "Collision" and "Cittàbapini" are more in line with the principle of experimental simultaneity Marinetti advocated, Kreymborg's play also seeks to attack the principle of theatrical realism. ${ }^{5}$

Rather than favoring realist acting techniques that would remain popular in American theater and eventually culminate in the Method Acting tradition, Kreymborg also wanted Loy and Williams to perform like two puppets, engaging with the innovative acting techniques developed by Gordon Craig, whose experiments also went against the grain of naturalism and sought to foreground the idea of art as artifice. Craig's texts like "The Actor and the Über-Marionette" (1908), where he developed his theory of the actor as a super-puppet, and his plays for puppets, published in the collection Drama for Fools, were important influences to Kreymborg's series of puppet plays. ${ }^{6}$ Craig wrote the preface to the 1923 edition of Kreymborg's Puppet Plays. All of these visual allusions to the aesthetics of the Futurists and Gordon Craig, whom Loy had known in Florence, also 
serve as oblique references to Loy's extravagant, cosmopolitan life, radically at odds with the mundane domesticity of her character. Thus, they further break the illusion of realism, making the work of the Provincetown Players seem conventional by comparison. Finally, the play is typically avant-garde in its turn to non-Western artistic practices to create an estrangement from the familiar; in the opening stage direction of Lima Beans, Kreymborg suggests: "Pantomime is modestly indulged by husband and wife, suggesting an inoffensive parody, unless the author errs, of the contours of certain ancient Burmese dances" (1918 43). Although Kreymborg himself was probably only vaguely familiar with what Burmese dance theater looked like, and this reference may be seen as typical of the early-twentieth-century Western trend for exoticism and Orientalist appropriation, Craig arguably had a higher degree of knowledge of Eastern puppets and acting traditions. In his chapbook Puppets and Poets, he dwells on the differences between puppets from various countries, including "Burmah." The chapbook also features an elaborate diagram of how a Japanese puppet is constructed. He also owned a collection of Burmese puppets, ${ }^{7}$ one of which has a costume strikingly resembling Mrs. Lima's [Ill. 2].

III. 2 Fonds Edward Gordon Craig (1872-1966). Bibliothèque nationale de France. Département des arts du spectacle.

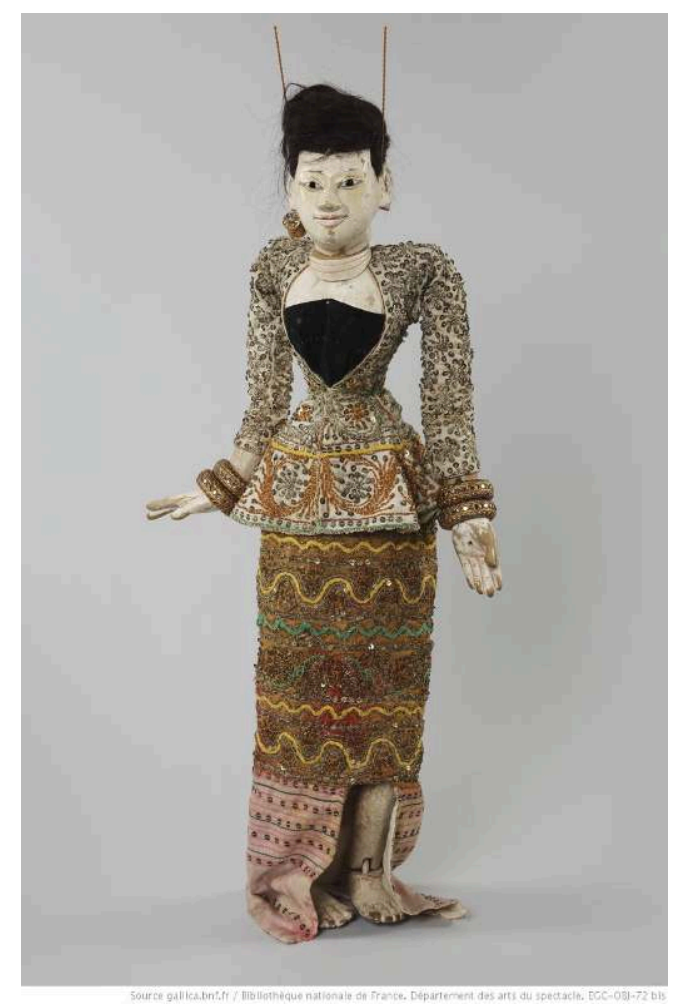

7 It is not certain that Kreymborg had seen these puppets, but Loy is likely to have seen them, and was possibly even inspired by this puppet for her costume. Thus, through Craig's influence, the play made an innovative-though admittedly inaccurate, as the word "parody" itself suggests-, use of Eastern acting traditions like Burmese puppet theater, which are representational but markedly not realist, creating a ritualistic stylization of the gestures that foregrounds the idea of art as artifice, and also merges theater and dance. 


\section{From Dance Poetry to Free-Verse Drama: Towards an Interarts Synthesis}

8 The attempt to merge drama with dance and other arts-particularly poetry-was at the core of Kreymborg's experimental project. The origins of this experiment may perhaps be found in a series of "Dance Poems" by the so-called "Choric School"-Hester Sainsbury, Kathleen Dillon, and John Rodker-, which had appeared in the October 1915 issue of Others. Ezra Pound's "Foreword to the Choric School," printed in the same issue, is indicative of the reception of such intermedial experiments in the modernist poetic circles:

I could not make much of [Rodker's] cadence until one evening [...] Miss Sainsbury and her company, including Miss Dillon, came in at the end of the hall and danced out their poems. I then understood the curious breaks and pauses, the elaborate system of dots and dashes with which this new group is wont to adorn its verses. [...] I was at once interested and excited by the possibility which their work has, a possibility of reanimating our verse. [...] Many hold that poetry was associated with dancing before men tried to wed words with music. At any rate the dance basis is fundamental in much early poetry. (1915 n. p.)

Since no recordings of the dance versions of works like Kathleen Dillon's two "Poems for Dancing," printed in the same issue, have survived, a contemporary reader may find it hard to make out the meaning of the poem's "system of dots and dashes," which look rather conventional compared to much other more experimental modernist poetry, in spite of the innovative potential of the idea itself. Nonetheless, as Pound's lines underscore, the attempt to bridge the gaps between the different arts by experimenting with hybrid, interarts forms was at the very heart of the modernist project as a whole. A poet and self-taught musician, Kreymborg took the promise of these hybrid forms a step further when, a couple of years later, he set out to experiment with theater forms in Lima Beans and the other "puppet" plays later collected in Plays for Poem-Mimes. As Murphy explains, the work of the Choric school that he had promoted in Others was a direct influence on the kind of interarts synthesis he sought to achieve in his plays:

In relation to Kreymborg's conception of theatre, John Rodker's composition, "Dutch Dolls," a Harlequinade whose characters are dolls with rhythmic, stylized movements, is particularly important. [...] The [...] 'Choric School' suggested a way in which Kreymborg's chosen media of music and poetry could be wedded to puppetry to create theatre. (105)

The attempts to bridge the gaps between the different arts, allying the techniques of dance, poetry, music, and drama, as well as puppet theater and pantomime, are omnipresent in Kreymborg's collection of plays: for example, When the Willow Nods, part of the same series as Lima Beans, was subtitled "A Dance-Play," while Lima Beans was subtitled "A Scherzo," also a musical term. In his memoir Troubadour, he writes that his goal in Lima Beans was to treat "the three characters of the plot as he might have handled a trio of instruments in a sonata movement" (1925 218-219). In the preface to the 1918 edition, Kreymborg presented his collection of plays by heavily alluding to other arts, defining his theater as a rhythmical free-verse poem, to be delivered with attention to the rhythm of the line and performed using an experimental acting technique inspired by pantomime, dance and puppetry: 
Plays for Poem-Mimes might be defined as pantomime acting or dancing of folk or automatons to an accompaniment of rhythmic lines, in place of music. [...] It is imperative that the reading tempo and the introduction of pantomiming shall adhere to the sense connotation rather than the rhythm of the lines. I have to make this small excursion into the realm of professorial instruction because the good people who have been kind as well as the good people who have been unkind to what is commonly and erroneously termed, free verse, have slipped into the error of scanning rather than of feeling the line divisions I offered in Mushrooms. (1918 6)

It is important to note that he makes an explicit parallel between his plays and his 1916 "Book of Free Forms" Mushrooms, which is usually classified as a free-verse poetry collection. In this preface as well as in Troubadour, he suggests that these "free forms," which often include dialogue, may be seen not only as poems but also as "the nucleus of a new type of playwriting" (1925 174). Interestingly, to any reader familiar with the principles of modernist poetic techniques, Kreymborg's insistence that when delivering the lines, actors should "adhere to the sense connotation" rather than mechanically scanning the rhythm of the lines, reads as an allusion to Pound's famous Imagist dictum "As regarding rhythm: to compose in the sequence of the musical phrase, not in the sequence of a metronome" (Pound 3). In Lima Beans, Kreymborg brought Pound's observations about the difference between the "sequence of the musical phrase" and the "sequence of a metronome" to a curiously literal dimension: in Troubadour, he remembers that he began rehearsals "by taking out a pencil and beating time while Mina and Bill read their lines" (1925 309). Murphy observes that since "Kreymborg had unorthodox ideas about the acting style he wanted, [Loy's and Williams's] lack of theatrical training was as much of a bonus as their understanding of the free-verse line and how to read it" (106-107). In other words, they were supposed to deliver their lines as poets, not as actors. Indeed, while this experimental attempt to create an interarts synthesis is at the core of the whole series of plays, Kreymborg's strategic casting of two of the most innovative modernist poets in the main parts of Lima Beans was particularly instrumental in reinforcing the idea of the play as a free-verse poem, creating a deliberate and meaningful blurring of roles. While casting poets in the main parts was a relatively rare practice, Lima Beans is clearly inscribed in a tradition of modernist intermedial experiment that Sarah Bay-Cheng and Barbara Cole call "modernist poetic drama" (13), an "attempt to resolve the division between poetry as literature and theater as performance" (14). ${ }^{8}$ Although Kreymborg's act of orchestrating the performance with his baton was not included in the show per se, one may see in this invisible metronome a clin d'œil not only to Kreymborg's own role as the editor of Others but also to Pound's key role as a maitre d'orchestre of the modernist movement. As Bay-Cheng and Cole argue, in such intermedial projects "the formal experimentation of the poetry [allowed modernists] to resist and subvert the apparent reality of the theater" (17). Unlike European avant-gardes like Dada and Futurism which drew on the confrontational aspects of theater, "American poets attempted to explore the communal aspects of the theater to engage a new audience for poetry" (Bay-Cheng and Cole 19). Thus, one of the key achievements of Lima Beans was to foster a community spanning both the page and the stage, allowing for far-reaching collaborative practices. Therefore, the play invites readings alongside the poetry that appeared on the pages of Others: the apparently light and amusing story of the play gains in importance when read in dialogue with Loy's and Williams's poems that appeared in Others in this period. 


\title{
Mina, Gina or Mrs. Lima? Loy Deconstructing "Marriage Boxes" between the Page and the Stage
}

\author{
Oh God \\ that men and women \\ having undertaken to vanquish one another \\ should be allowed \\ to shut themselves up in hot boxes and breed \\ (Loy, 1982 143)
}

The plot of Kreymborg's play has been dismissed as a light, amusing parody, and, perhaps unsurprisingly, has prompted very little critical analysis. Murphy, among the few scholars who offer a critical interpretation of the play, reads it as "an epithalamium, or bridal song, about a young couple who are just two weeks married" (109), suggesting that the "lima beans" and "string beans" may have hidden symbolism, standing for different kinds of sexual practices for the married couple. Regardless of whether one reads the play's conflict on the level of sexual or culinary tastes, what is clear is that in this satire of the quarrels of married life, marital bliss and peace depend on the wife's unconditional submission: she must forgo her wishes and serve her husband his beloved lima beans. The opening scene, which finds "The Wife" setting the table for dinner, is emblematic of the blind submission and blithe subservience to her husband that seem to be Mrs. Lima's only character trait:

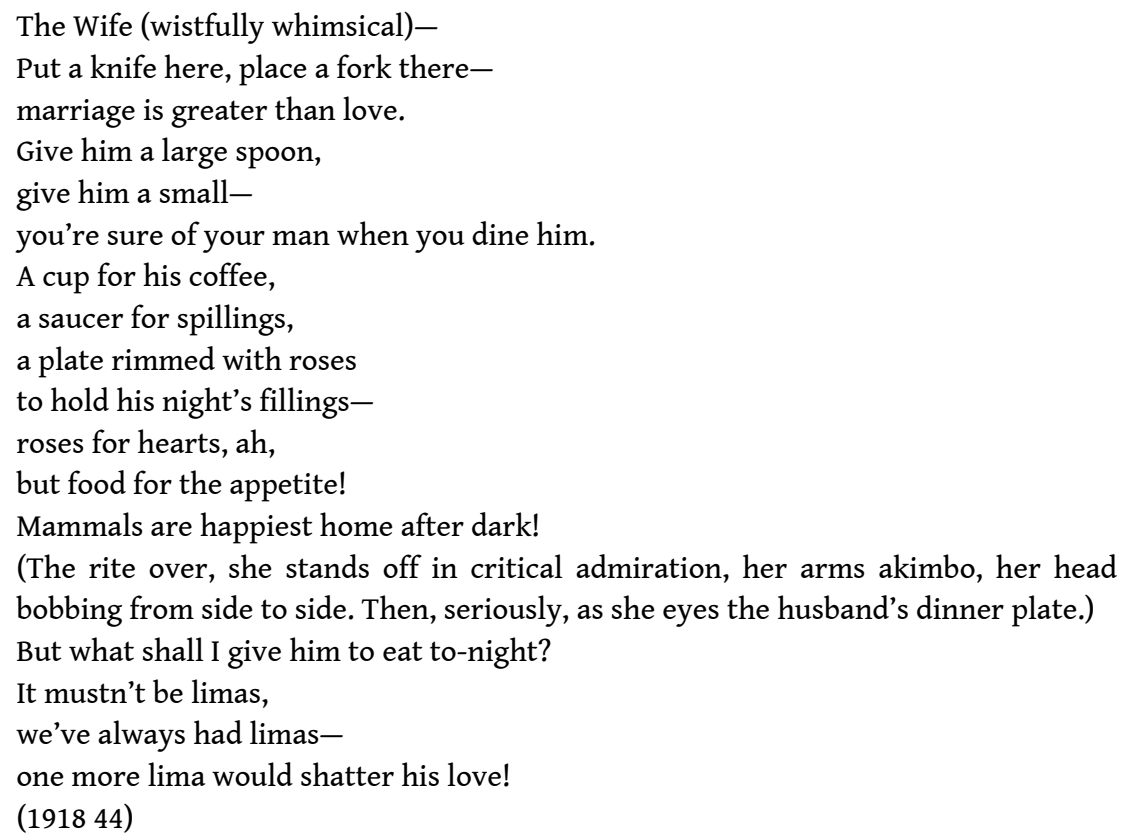

13 Casting Loy as the wife may at a first glance seem something of a mismatch, and no one was more aware of this than Kreymborg himself, who observed that the part was "much too light for a person of Mina's worldly experience" (1925 309). Elsewhere, he had eloquently described her mythic reputation of an "exotic and beautiful" poet famous for her "madly elliptical style scornful of the regulation grammar, syntax, and punctuation" (1929 488). The contrast is also stylistic: compared to Loy's own baffling and daringly innovative poems, as well as to her highly experimental Futurist plays published in Rogue in 1915, ${ }^{9}$ the "poetry" of this free-verse play, strewn with occasional rhymes-looks ironically tame, domestic, and down-to-earth, foregrounding the contrast between Loy the poet and Loy "the Wife." Paradoxically, in spite of 
Kreymborg's insistence that the play's dialogue must be read as free verse, there is a humorous musicality in the lines, which are often surprisingly metrical, as foregrounded by the use of dactylic feet (such as "wistfully whimsical" or "marriage is greater than love"). There is even a line that sounds like an iambic pentameter-"But what shall I give him to eat to-night?"-which seems to ironically sum up the Wife's entire raison d'être. The play seems to align the lull of the humorous musicality of the lines with the ritualized conventions of marriage, creating an implicit contrast with the jarring rhythms and fragmented syntax of Loy's poems. On the visual level, the sense of discrepancy between Loy and her character was further reinforced by her costume, a "fashionable décolleté gown" that she had designed herself, and which was markedly not "in keeping with Mrs. Lima" (1925 310) as Kreymborg observed. The costume, which consisted of "a green taffeta gown, gold slippers, and pieces from her jewelry collection, including a mosaic brooch, dangling gold earrings, and ornate English rings" (Murphy 107), introduced an exotic touch, strategically breaking with the illusion of realism and creating an estrangement effect from the banal domestic scene. ${ }^{10}$

Arguably, Kreymborg's choice of having a worldly, highly sophisticated and cosmopolitan avant-garde female poet engage in a deliberately banal and insipid narrative of domesticity and marriage in order to create an estrangement effect of sorts owes something to the implicit theatricality of Loy's own poem, "The Effectual Marriage / or / The Insipid Narrative / of / Gina and Miovanni" (ca. 1915). First published in Others: An Anthology of the New Verse (1917), it was later praised as a particularly outstanding example of modernist poetic technique by both Ezra Pound and T.S. Eliot. ${ }^{11}$ In this poem, Loy uses thinly veiled anagrams for the names of the protagonists, casting herself and Futurist Giovanni Papini, with whom she had a brief liaison in Florence, as husband and wife in a mocking representation of an "insipid" conventional marriage. Apart from being a transparent allusion to Papini's name, "Miovanni" also conjures up the sentimental address amore mio, ${ }^{12}$ while "Gina" refers not only to Loy herself, but also functions as an embodiment of an essentialized female identity, reduced to the stereotypical gender roles of a spouse and housewife. Loy's self-casting as "Gina" suggests that she understood gender as performance, long before it was theorized as such. As Churchill observes, the effect of the poem hinges to a great extent on the strategic aloofness of the position of the speaker-both author of the "narrative" and one of its main characters, critical subject and object of the satire: "Loy makes herself both author and butt of her own satire: she exists both inside and outside the poem, refusing to occupy a stable position as spectator or participant in the narrative" (2006 202). Loy's costume in the play, clearly evocative of her reputation as a dazzling, emancipated, exotic and sophisticated female poet, but radically at odds with the domesticity of her stereotypical character, creates a similar effect of estrangement and aloofness from the story itself. As Laura Scuriatti observes, Loy was herself transformed into "the character "Mina Loy"' (72) in avant-garde circles, an incarnation of a quasi-mythic, dazzling, eccentric and emancipated "Modern Woman"-the exact opposite of both Gina and Mrs. Lima, a contrast which is implicitly present in both the poem and the play. Like Mrs. Lima, Gina spends her whole day in the kitchen, busying herself among pots and pans, ${ }^{13}$ and happily pondering on the greatness of marriage:

In the evening they looked out of their two windows

Miovanni out of his library window

Gina from the kitchen window

From among his pots and pans 


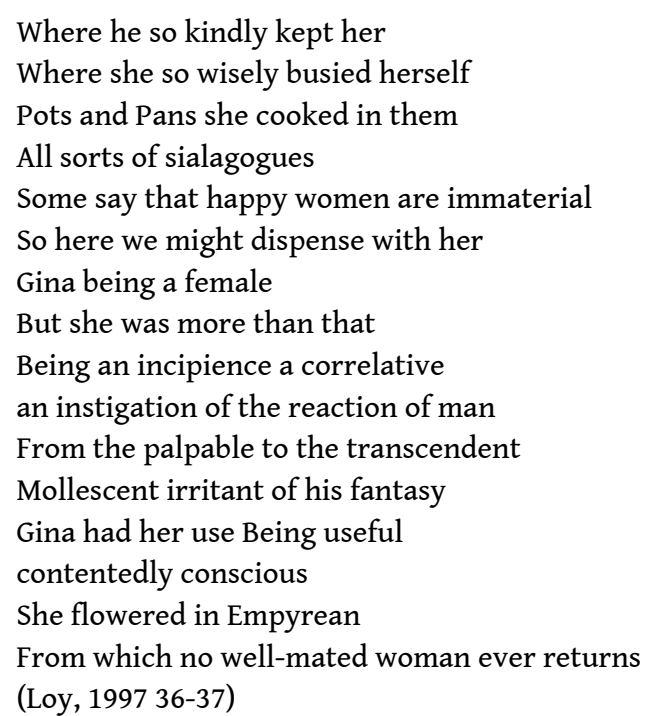

While it cannot be proven with absolute certainty that Kreymborg had already read Loy's poem when he wrote the play, Mrs. Lima's recitation of platitudes like "marriage is greater than love" and "Mammals are happiest home after dark" seems very close to the poem's insistence that "happy women are immaterial" and that marriage is an "Empyrean / From which no well-mated woman ever returns," a kind of prescriptive collective voice lauding marital bliss. Kreymborg's "Mrs. Lima" seems like a scenic embodiment of Loy's Gina, whose whole being is easily reduced to "Being useful" to her husband, not having an opinion of her own, always ready to comply with her husband's tastes or wishes: "Patience said Gina is an attribute / And she learned at any hour to offer / The dish appropriately delectable" (Loy, 1997 37).

As both Scuriatti and Churchill have argued, a focus on space as related to gender divisions and constraints predominates in "The Effectual Marriage": "[the poem's] structural principle is an architectural space-a house that both describes and prescribes the limits of a marital relationship" (Churchill, 2006 201). Kreymborg's play has a similar focus on domestic spaces, which are essentially spaces of confinement for women, as the opening stage direction makes it clear: "The scene is a miniature dining room large enough to contain a small table, two chairs, a tiny sideboard, an open window, a closed door leading to the other rooms, and additional elbow space" (Kreymborg, 1918 43)..$^{14}$ While the husband freely goes in and out, the wife (both Gina and Mrs. Lima) is confined to the kitchen, as emphasized by the alliterations ("kitchen," "kindly," "kept"), a prisoner among her husband's "pots and pans," and may only use the "kitchen window" to manage the household by talking to the vegetable huckster. One may note that as in Loy's poem, the play's claustrophobic space is structured by a door and a window, and orchestrated by the husband's comings and goings, as well as by the dealings with the huckster through the window: "Boundary areas such as windows and doors are endowed with the possibility of change and transformation, but they also simultaneously function as loci in which the ideological force of spatial structures is at its strongest" (Scuriatti 73). Although Kreymborg's dissection of the politics of marriage and domestic spaces is less thorough than Loy's, as the happy ending suggests, Loy's poem and Kreymborg's play can be read as a single, palimpsestic text $\mathrm{t}^{15}$ deconstructing "marriage boxes," with connections reinforced by Loy's ironically aloof presence in both repressive spaces. 


\section{Marriage between "Burmese Dances" and "Dance Russe": Williams's Domestic Modernism in Performance}

17 Loy's poem is an acerbic, biting feminist satire, which targets the combined dimensions of Futurist misogyny, her own unhappy marriage of convenience to the painter Stephen Haweis after an unwanted pregnancy, and the particularly stifling and rigid gender roles of patriarchal societies like Italy where she was living at the time of the composition of the poem. In comparison, Kreymborg's play tackles the same themes in a much more humorous, light-hearted and amusing manner, and its take on marriage and domesticity looks more inoffensive. This more blithe, playful, and amusing tone of the work, which is characteristic of Kreymborg's style, perhaps also owes something to the fact that William Carlos Williams, rather than the misogynistic Papini, was cast in the role of the husband: Kreymborg thus invited spectators to read his performance alongside Williams's textual poetics, and particularly the way it engages with the theme of the everyday, marriage and domesticity. For instance, the joyful litany of the Huckster amounts to a Williams-like paean to vegetables and fruit, celebrating the simple pleasures of food as a source of marital harmony and family bliss ${ }^{16}$ :

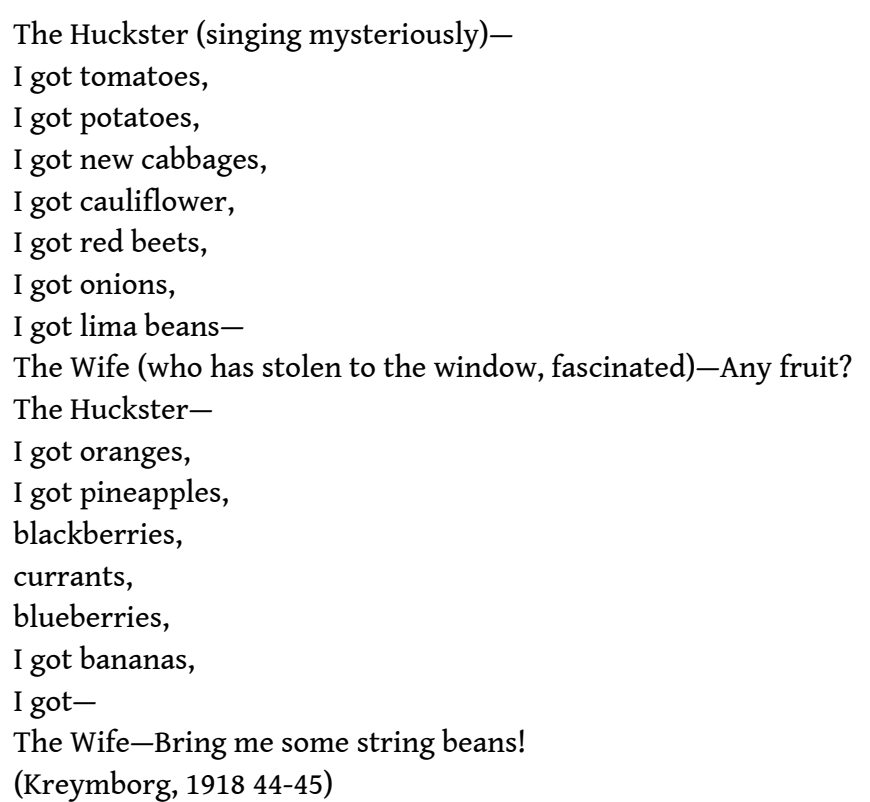

18 Apart from introducing a comic proto-absurd touch, the repetition and conspicuously misplaced stresses draw the spectators' attention to the tension between word and thing, not unlike Williams's Imagist poetics that achieves a similar effect through the use of line breaks isolating certain words on the line, for example in his famous later poem "This is Just to Say": "I have eaten / the plums / that were in the icebox [...] they were delicious / so sweet / and so cold" (Williams, 1991 372). There are indeed some interesting correspondences between the play and two of Williams's poems that appeared in the December 1916 issue of Others-"The Young Housewife" and "Dance Russe." Just like Kreymborg's play and Loy's poem discussed above, both of these poems have a focus on domestic spaces, and particularly on the division between spaces traditionally marked "feminine" and those marked "masculine." It is useful to compare "Gina" and "Mrs. Lima" with "The Young Housewife" from Williams's 
eponymous poem, as all three are constructions of female identity reduced to the role of the wife:

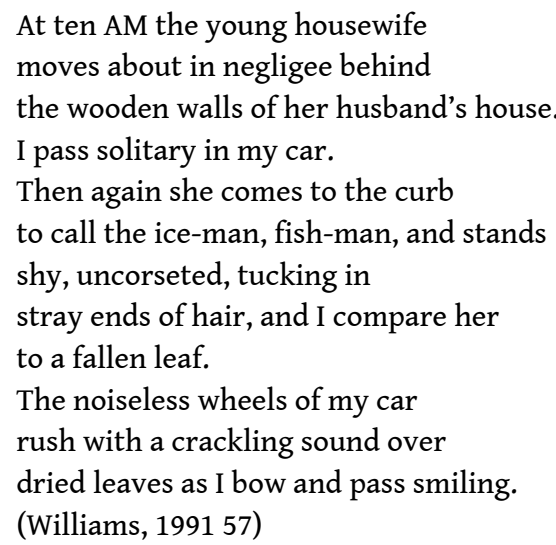

19 This housewife seems to be another possible textual inspiration for Kreymborg's play: like Mrs. Lima who spends her time talking to the vegetable huckster while awaiting the return of her husband, the young housewife in Williams's poem only exits "her husband's house" to "call the ice-man, fish-man." While Loy's critical feminist viewpoint emphasizes the stifling aspect of the relationship, Williams's masculine point of view foregrounds the aestheticized and eroticized female body ("in negligee," "uncorseted," etc.) as an object of admiration and desire ("I pass smiling"). In the play, it is possibly the huckster or even the spectator who is placed in the position of the external observer of the poem, since Mrs. Lima is clearly cast as an object of desire, as her low-cut dress suggests. Notwithstanding, even in Williams's poem the housewife is "behind / the wooden walls of her husband's house" (as opposed to her own or their shared house). This subtle reference to the economic dependence of women on men recalls the similar opposition between Giovanni's privileged position at "his library window" and Gina's occupation of "the kitchen window" (Loy, 1997 36, emphasis added) in Loy's "Effectual Marriage," foregrounding the fact that the wife is herself closer to one of her husband's possessions rather than to someone who can possess anything herself.

Just as Loy's poem hinges on a split between the blithe, submissive figure of the wife, ironically posited as an alter ego of Loy herself, and the acutely critical eye of the observer of the domestic scene, another alter ego of the poet, Williams's two poems foreground a tension between different incarnations of masculine identity. Some are closer to an external observer, while others are closer to the figure of the husband, thus playing with the divides inside / outside and subject / object. While in "The Young Housewife" the speaker is an external observer, "pass[ing] solitary in [his] car" and eager to take the place of "the [absent] husband," in the poem "Dance Russe," "the husband" is clearly posited as an alter ego of the poet himself, who is nonetheless capable of observing himself through a detached, external stance:

If I when my wife is sleeping

and the baby and Kathleen

are sleeping

and the sun is a flame-white disc

in silken mists

above shining trees,-

if I in my north room

dance naked, grotesquely 


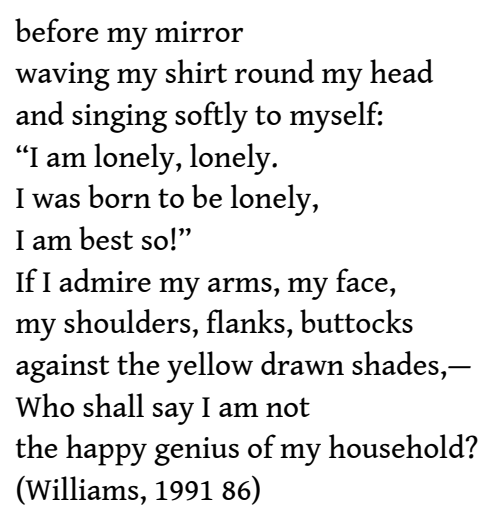

21 The poem hinges on a split between two figures that Barry Ahern eloquently calls "Dr. Williams and Mr. Hyde," ${ }^{17}$ as both are alter egos of Williams himself. On the one hand, there is "the happy genius of my household," the husband and father content with his middle-class, suburban existence, and on the other there is a figure that encapsulates everything that is suppressed and excluded in this ideal narrative of marital bliss and peaceful domesticity. The repetition of the pronoun "my" throughout the poem charts this split, which suggests that the husband both needs his wife and children and/as possessions ("my wife," "my household") and finds them insufficient, needing a space for the irrational impulses marriage excludes ("my north room," "my mirror," "my shirt round my head," etc.). The poem provides a space in which these impulses may be "safely" played out in a conditional, i.e. imaginary modality ("If I"). The "grotesque" and homoerotic scene of the husband caught secretively and solipsistically engaging in the irrational act of admiring his naked body in the mirror, and feeling lonely in spite of all the happiness he is supposed to feel, vividly captures everything that is excluded from the narrative of domesticity and marriage. Lima Beans suggests as much when the husband gets upset for no apparent reason and leaves when seeing the string beans instead of his favourite lima beans, delivering a long nonsensical monologue and calling his wife a "Traitress" (Kreymborg, 1918 52). In that sense, the solipsistic, homoerotic scene of "Dance Russe" may be read as an addendum to the play: a soliloquy for Mr. Lima, it bridges the gap left by his unexpected exit, with the alternative space of the page providing an outlet for impulses that are excluded from the rational, heteronormative space of marriage, here aligned with the space of the stage. While Williams's poems are often read as an unambiguous praise of peaceful, everyday life, this poem foregrounds the ambivalence towards marriage and domesticity that lies at the core of his poetry. It also alludes to Williams's own "double life" as an exemplary doctor, husband and father who nonetheless often spent his evenings at the Arensbergs's apartment or rehearsing Lima Beans in the company of Mina Loy rather than at home with his wife. ${ }^{18}$ The "Mrs. Lima" character in Kreymborg's play-an incongruous combination between a submissive housewife and a seductive, dazzling beauty with a low-necked dress-captures this impossible duality.

There is an interesting correspondence between Williams's idea of "Dance Russe" as a metaphor for the irrational impulses breaking the regular, harmonious rhythm of marriage, and Kreymborg's idea that the "pantomime" of the two puppet-characters of Lima Beans may be compared to a parody of "certain ancient Burmese dances" (Kreymborg, 1918 43). Of course, the allusions to both Burmese and Russian artistic practices are to be read metaphorically, as modernist reinventions of the Other. As already suggested above, the main purpose of the allusion to the technique of Burmese 
puppetry is to break with the illusion of domestic realism, suggesting that the gestures and rituals prescribed by gender roles in patriarchal society are not something natural but something subconsciously acquired through social traditions. By contrast, Williams's grotesque, naked "Dance Russe" creates an irrational Expressionist element that radically intrudes into and breaks with the rational ideal and regular rhythm of peaceful domesticity. The title itself is ostensibly an allusion to the experimental dance techniques of the Ballets Russes, which broke the harmony of traditional folklore dance motifs, revolutionizing them through a use of dissonance and syncopated rhythms. So, if one may understand "Burmese dances" as a metaphor-though admittedly an Orientalist one-for the carefully orchestrated movements and regular rhythms of married life, as related to ritual and tradition, Williams's "Dance Russe" may be seen as a metaphor for dissonant, irrational movements that break with these carefully orchestrated harmonies. Thus, Williams's ambivalent presence in the role of the husband enriches the play's meanings, charging the theatrical space with the ambiguities and hesitations that characterize his own poetry.

\section{Conclusion}

A free-verse poem in performance, Lima Beans was created collaboratively and charged with the meanings of the poets' individually composed intertexts. Charting farreaching connections between the page and the stage, and creating an intermedial space allowing those involved in it to get into the shoes of their own textual alter egos, it deconstructed gender roles and tested the limits of dominant narratives. Although Kreymborg authored the play itself, as the play's director he gave the two poets ample space to experiment with their roles. Reading the play alongside Loy's and Williams's poems provides the subtle nuance, ambivalence and complexity that its somewhat schematic story seems to lack at a first glance. Combined with elements like the abstract sets, the incongruous costumes, the nonsensical dialogues and the puppet-like acting techniques, Kreymborg's experimental collaborative interarts synthesis foregrounds the limitations of and creates an estrangement effect from the dominant tradition of domestic realism in theater. It gives the promise of an alternative theater, which takes the form of an intermedial and intertextual experimental laboratory.

\section{BIBLIOGRAPHY}

AHERN, Barry. William Carlos Williams and Alterity: The Early Poetry. Cambridge: Cambridge University Press, 1994.

BARTOLI, Francesco. "La Surmarionnette de Craig préambule à la scène abstraite." Puck, No. 1: L'avant-garde et la marionnette. Ed. Brunella Eruli. Charleville-Mézières: Éditions de l'Institut international de la marionnette, 1988. 
BAY-CHENG, Sarah, and Barbara COLE, eds. Poets at Play: An Anthology of Modernist Drama. Selinsgrove: Susquehanna University Press, 2010.

BURKE, Carolyn. Becoming Modern: The Life of Mina Loy. New York: Farrar, Straus and Giroux, 1996. CHURCHILL, Suzanne. The Little Magazine Others and the Renovation of Modern American Poetry. Aldershot: Ashgate, 2006.

CHURCHILL, Suzanne. “Courting an Audience: Loy's Plays.” Mina Loy: Navigating the Avant-Garde. Eds. Suzanne W. Churchill, Linda Kinnahan, and Susan Rosenbaum. University of Georgia, 2020. https://mina-loy.com/chapters/courting-an-audience/. Accessed 11 September 2020.

CRAIG, Gordon. Puppets and Poets. London: The Poetry Bookshop, 1921.

CRAIG, Gordon. Le théâtre des fous = The Drama for Fools. Ed. Didier Plassard. Montpellier Charleville-Mézières : Institut international de la marionnette, 2012.

CRAIG, Gordon. On the Art of the Theatre. London: Heinemann, 1929.

CRAIG, Gordon. “The Actor and the Über-Marionette.” The Mask, vol. 1, no. 2, 1908, p. 3-8.

CRAIG, Gordon. Fonds Edward Gordon Craig (1872-1966).

gallica.bnf.fr/ark:/12148/btv1b10060023p/f11.item.r=Craig\%20marionnettes\%20birmanie. Accessed 18 August 2020.

GLASPELL, Susan. Trifles: A Play in One Act. Boston: Walter H. Baker, 1951.

KREYMBORG, Alfred. Plays for Poem-Mimes. New York: The Other Press, 1918.

KREYMBORG, Alfred. Mushrooms: A Book of Free Forms. New York: Alfred A. Knopf, 1916.

KREYMBORG, Alfred. Puppet Plays. Introduction by Gordon Craig. New York: Harcourt, Brace and Company, 1923.

KREYMBORG, Alfred. Troubadour: An Autobiography. New York: Boni and Liveright, 1925.

KREYMBORG, Alfred. Our Singing Strength: An Outline of American Poetry (1620-1930). New York: Coward-McCann, 1929.

KUENZLI, Rudolf E., ed. New York Dada. New York: Willis Locker \& Owens, 1986.

LOY, Mina. The Lost Lunar Baedeker. Ed. Roger L. Conover. New York: Farrar, Straus and Giroux, 1996.

LOY, Mina. The Last Lunar Baedeker. Ed. Roger L. Conover. Highlands: Jargon Society, 1982.

LOY, Mina. Two Plays [“Collision” and “Cittàbapini”]. Rogue, n 1, 1915, p. 15-16.

MARINETTI, Filippo Tommaso. “The Variety Theater.” 1913. Futurism: An Anthology. Eds. Christine Poggi, Laurence Rainey, and Laura Wittman. New Haven: Yale University Press, 2009. p. 159-164.

MARINETTI, Filippo Tommaso, Emilio Settimelli, and Bruno Corra. "The Futurist Synthetic Theater." 1915. Futurism: An Anthology. Eds. Christine Poggi, Laurence Rainey, and Laura Wittman. New Haven: Yale University Press, 2009. p. 204-209.

MONTEIRO, George. “Carlos Williams, Actor.” William Carlos Williams Review, vol. 27, no. 1, 2007, p. 69-70.

MURPHY, Brenda. The Provincetown Players and the Culture of Modernity. Cambridge: Cambridge University Press, 2005.

NAUMANN, Francis M. New York Dada 1915-23. New York: Harry N. Abrams, 1994. 
NAUMANN, Francis M., ed. Making Mischief: Dada Invades New York. New York: Whitney Museum of American Art, 1996.

PRAMPOLINI, Enrico. “Futurist Stage Design.” 1915. Futurism: An Anthology. Eds. Christine Poggi, Laurence Rainey, and Laura Wittman. New Haven: Yale University Press, 2009. p. 212-215.

POUND, Ezra. “A Retrospect.” Literary Essays of Ezra Pound. New York: New Directions, 1968, p. 3-14.

POUND, Ezra. "Foreword to the Choric School." Others, vol. 1, no. 4, 1915, p. C-D.

SCURIATTI, Laura. "Negotiating Boundaries: The Economics of Space and Gender in Mina Loy's Early Poems," Feminismo/s, no. 5, 2005, p. 71-84.

VOYCE, Stephen. “'Make the World Your Salon': Poetry and Community at the Arensberg Apartment." Modernism/modernity, vol. 15, no. 4, 2008, p. 627-647.

WILLIAMS, William Carlos. The Autobiography of William Carlos Williams. New York: New Directions, 1967.

WILLIAMS, William Carlos. I Wanted to Write a Poem: The Autobiography of the Works of a Poet. Ed. Edith Heal. New Directions, 1977.

WILLIAMS, William Carlos. The Collected Poems of William Carlos Williams, Vol. 1: 1909-1939. Eds. A. Walton Litz and Christopher MacGowan. New York: New Directions, 1991.

\section{NOTES}

1. Edna Kenton, review of Lima Beans, qtd. in Murphy, Brenda, The Provincetown Players and the Culture of Modernity, 108.

2. See The Little Magazine Others and the Renovation of Modern American Poetry.

3. The Arensberg circle, sponsored by collectors Walter and Louise Arensberg, also included Kreymborg and the group of poets associated with Others, as well as the group of mostly expatriate European visual artists that would later become known as New York Dada. Loy herself is a figure associated both with Others and with New York Dada. Concerning the importance of community and collaboration in the Arensbergs' salon, see Stephen Voyce, "Make the World Your Salon': Poetry and Community at the Arensberg Apartment." Concerning New York Dada, see Francis Naumann (ed.), Making Mischief: Dada Invades New York.

4. "Marriage Boxes" is the title of a section in Loy's poem "Anglo-Mongrels and the Rose." Although this poem was not published until the 1920s, satirizing marriage, traditional gender roles, and domesticity as stifling for women was already a major preoccupation of Loy's poetry through the 1910s.

5. Lima Beans also applies the principle of "hilarity in dialogue, the negative act, the reechoing one-liner" (Marinetti, Settimelli and Corra 208) that the Futurists called for in "The Futurist Synthetic Theater."

6. In 1921, Craig published a chapbook titled Puppets and Poets, which provided the inspiration for the title of the present article. See also his theoretical treatise On the Art of Theater, as well as Francesco Bartoli's article "La Surmarionnette de Craig préambule à la scène abstraite."

7. Gordon Craig's Burmese puppet collection is available online on Gallica.

8. Bay-Cheng and Cole's anthology includes plays by Williams and other writers who moved in Kreymborg's artistic circles-like Wallace Stevens or Edna St. Vincent Millay. They argue that it was Kreymborg's Lima Beans that "first introduced experimental poetic drama to the Provincetown Players" (33). More broadly speaking, Lima Beans can also be seen as part of the 
modernist undertaking to do away with the boundaries between the different genres, as for example by Williams in Spring and All.

9. See "Collision" and "Cittàbapini," published in Rogue in 1915. Suzanne Churchill also points out the striking similarity between the cover of Rogue and the Futurist sets of Lima Beans, which reinforces her idea of little magazines as theaters (2017 n. p.)

10. It is tempting to speculate that Loy may have modelled her costume on the Burmese puppet of a princess owned by Craig. Several aspects, like the low-cut décolleté, the long tight skirt, the ornate jewelry, and the arrangement of the hair, point to this.

11. Pound printed excerpts of the poem in two anthologies, under the title "The Ineffectual Marriage." For more details, see Churchill, The Little Magazine Others, 206-211.

12. An equivalent of this may be found in the excessively mawkish sentimentality of Mr. and Mrs. Lima, whose ritual of six kisses is repeated at regular intervals throughout the play.

13. This was nonetheless a condition also familiar to Loy, who experienced a long period of dissatisfaction with the drudgery of being a housewife, and more generally speaking with the emptiness and hypocrisy of marriage, during her first marriage to Stephen Haweis in Paris and Florence, prior to her participation in Lima Beans.

14. This interest in staging the architecture of married life is also evident in other, more realist Provincetown Plays such as Susan Glaspell's Trifles, which similarly defines domestic interiors as spaces of confinement, gendered feminine.

15. I want to thank the anonymous reviewer of this essay who pointed out that the correspondences between Loy's early writings and Lima Beans seem to suggest that Loy could have played a role not just acting in the play, but also in revising the script and designing the set and costumes. Even if Kreymborg wrote the script on his own, the performance was nevertheless a collaborative effort in which Loy may have played a bigger part than the one visible on stage.

16. Williams celebrates these pleasures notably in later poems like "Child and Vegetables" and "This is Just to Say."

17. See the chapters "Dr. Williams and Mr. Hyde" and "Love and Marriage" in Ahern's William Carlos Williams and Alterity, 1-54.

18. In his autobiography, Williams dwells on his infatuation with Loy: "I had a flirtation with Mina-fruitless." (Williams, 1977 34).

\section{ABSTRACTS}

This article focuses on a little-explored case of modernist collaboration situated at the crossroads between different arts: the performance of Alfred Kreymborg's play Lima Beans, produced by the Provincetown Players in December 1916, in which poets Mina Loy and William Carlos Williams played the two leading parts, together with poet and artist William Zorach, who also designed the sets. The play's novel aesthetics breaks with the principles of the realist dramas typical of the time and favored even by more experimental groups like the Provincetown Players. First, the article examines how the play creates a distancing effect towards the deliberately mundane story of a married couple, using incongruous elements like the proto-absurdist nonsense of the dialogues, the abstract, Futurist sets, and the groundbreaking acting techniques inspired by puppet theater. Second, it specifically focuses on the blurring of the boundaries between the different arts-drama, poetry, and dance among others-in this play, whose dialogues were conceived as free verse. Finally, it delves into the intertextual and intermedial dialogues between 
the play and Loy's and Williams's poems published in the little magazine Others, edited by Kreymborg.

Cet article se penche sur un cas peu exploré de collaboration moderniste qui se situe au carrefour de plusieurs arts : la pièce Lima Beans, écrite et mise en scène par Alfred Kreymborg et produite par les Provincetown Players en décembre 1916. Dans cette mise en scène, les poètes modernistes Mina Loy et William Carlos Williams jouent les rôles principaux, accompagnés du poète et artiste peintre William Zorach, également responsable des décors. L'esthétique novatrice de cette mise en scène rompt avec les principes du théâtre réaliste typique de l'époque et prôné même par des groupes plus expérimentaux comme les Provincetown Players. Dans un premier temps, cet essai étudie l'effet de distanciation produit par la pièce envers l'histoire délibérément banale du quotidien d'un couple marié, à travers des éléments incongrus comme les dialogues protoabsurdistes, les décors abstraits aux touches futuristes, et les techniques de jeu inspirées du théâtre de marionnettes. Dans un deuxième temps, l'essai revient sur la synthèse entre les différents arts-théâtre, poésie et danse entre autres-qui affleure dans cette pièce, dont les répliques ont été conçues comme des vers libres. Sont étudiés enfin les dialogues intertextuels et intermédiaux entre la pièce et certains des poèmes de Loy et Williams publiés dans la revue Others, dont Kreymborg était le rédacteur en chef.

\section{INDEX}

Mots-clés: modernisme, avant-garde, théâtre expérimental, Alfred Kreymborg, Mina Loy, William Carlos Williams, little magazines, Provincetown Players, futurisme, dada, Gordon Craig

Subjects: Hors-thème

Keywords: modernism, avant-garde, experimental theater, Alfred Kreymborg, Mina Loy, William Carlos Williams, little magazines, Provincetown Players, Futurism, Dada, Gordon Craig

\section{AUTHOR}

\section{YASNA BOZHKOVA}

Sorbonne Nouvelle 